\title{
BARRIERS TO INFORMED REFUSAL IN KOREA
}

\author{
Claire Junga $\mathrm{Kim}^{1}$
}

\begin{abstract}
In South Korea, the legal and cultural environment keeps terminally ill patients from making an informed refusal to a treatment the discontinuation of which can cause death. Act on Decisions on Life-Sustaining Treatment for Patients in Hospice and Palliative Care or at the End of Life allows several forms of informed refusal, but it is not enough. There is no explicit guarantee, at least under this law, of the right to refuse a treatment given during a period that has not reached an endof-life process prescribed in the law. Dori, which the family of a terminal patient feels obligated to follow, makes them commit to doing what they believe is right as a family member without asking the patient's intention. Because it reduces the family's motivation to have a difficult talk about death and end-of-life with the patient, the patient is deprived of an opportunity to make a decision based on accurate information. In making a decision for the patient while patient is excluded, the family often ends up choosing a safe decision that puts physical survival first. In conclusion, the culture and the culturally influenced law are making it impractical for terminal patients to make an informed refusal.
\end{abstract}

Keywords: treatment refusal, informed refusal, terminal patients, terminal care, life-sustaining treatment

\section{Obstáculos al rechazo informado en Corea}

Resumen: En Corea del Sur, el entorno legal y cultural impide a los pacientes terminales rechazar con conocimiento de causa un tratamiento cuya interrupción puede causar la muerte. La Ley de Decisiones sobre el Tratamiento de Mantenimiento de la Vida para Pacientes en Hospicio y Cuidados Paliativos o al Final de la Vida permite varias formas de rechazo informado, pero no es suficiente. No se garantiza explícitamente, al menos en esta ley, el derecho a rechazar un tratamiento administrado durante un periodo que no ha llegado a un proceso de final de vida prescrito en la ley. La ley Dori, que la familia de un paciente terminal se siente obligada a seguir, les hace comprometerse a hacer lo que creen correcto como familiares, sin preguntar la intención del paciente. Dado que reduce la motivación de la familia para tener una charla difícil sobre la muerte y el final de la vida con el paciente, éste se ve privado de la oportunidad de tomar una decisión basada en información precisa. Al tomar una decisión por el paciente mientras se le excluye, la familia suele acabar eligiendo una decisión segura que antepone la supervivencia física. En conclusión, la ley, influenciada por la cultura, está haciendo que sea poco práctico para los pacientes terminales hacer un rechazo informado.

Palabras clave: rechazo de tratamiento, rechazo informado, pacientes terminales, cuidados terminales, tratamiento de mantenimiento de la vida

\section{Barreiras à Recusa Informada na Coreia}

Resumo: Na Coreia do Sul, o ambiente legal e cultural mantém pacientes com doença terminal à parte de fazer uma recusa informada a um tratamento cuja descontinuação pode causar morte. O Ato sobre Decisóes a respeito de Tratamento de Suporte à Vida para Pacientes em Lares de Idosos e Cuidados Paliativos ou ao Fim da Vida permite diversas formas de recusa informada mas não é suficiente. Não há uma garantia explícita, pelo menos sob esta lei, do direito de recusar um dado tratamento durante um período que não alcançou um processo de fim-da-vida prescrito na lei. Dori, que a família de um paciente terminal sente-se obrigada a seguir, faz com que eles se comprometam a fazer o que eles acreditam ser certo como um membro da família, sem perguntar a intençáo do paciente. Na medida em que isto reduz a motivação da família em ter uma conversa difícil sobre morte e fim-da-vida com o paciente, o paciente é privado de uma oportunidade de tomar uma decisão baseada em informação precisa. Ao tomar uma decisão pelo paciente enquanto ele é excluído, a família frequentemente termina escolhendo uma decisão segura que coloca a sobrevivência física em primeiro lugar. Em conclusão, a cultura e a lei influenciada pela cultura estão tornando impraticável para pacientes terminais fazer uma recusa informada.

Palavras chave: Recusa ao tratamento, Recusa informada, Pacientes terminais, Cuidados terminais, Tratamento de suporte à vida

\footnotetext{
${ }^{1}$ Department of Medical Humanities, Dong-A University College of Medicine, Busan, Korea. ORCID: 0000-0001-6889-5478. Correspondence: clairejungakim@gmail.com
} 


\section{Introduction}

Informed refusal on medical treatment is a fundamental way of respecting patients' autonomy. Although it cannot be seen as an absolute right, the right to refuse medical treatment is regarded as constitutional(1) or implied in informed consent(2), which is the most widely accepted rule in modern bioethics. There has been much discussion on the extent to which the right for informed refusal should be respected on various individual cases: cases where a third party such as a fetus(3) or public in communicable diseases(4) will be harmed by the refusal; a case where a mature minor refuses(5); or a case where a patient seems to make a unreasonable choice(6). However, a competent adult's refusal to medical treatment that has no substantial harm to others is generally accepted. Moreover, informed refusal on aggressive life-sustaining treatment in one's end-of-life is regarded as taking one's first step for choosing palliative medicine. The national health system (NHS) of United Kingdom explicitly declares that a decision to refuse treatment must be respected, "even if is thought that refusing treatment would result in your death(7)".

However, in Korea, informed refusal is practically impossible or hindered by numerous obstacles, when withdrawal of a treatment could lead to the death of a patient. As the majority of treatments to critically ill patients fall under a category wherein cessation of treatment could result in the patient's death, the scope of how much one's right to selfdetermination can be exercised is limited. The Act on Decisions on Life-Sustaining Treatment for Patients in Hospice and Palliative Care or at the End of Life(8), hereafter the Act, enacted in 2016 and enforced in 2018. It allows several forms of informed refusal; however, these are insufficient. The Act stipulates a patient's right to withdraw life-sustaining treatments but defines those as treatments that merely extend the duration of the end-of-life process without curative effect, excluding the treatments that are provided before one's end-of-life process by definition. Therefore, the right to refuse treatment by a patient not at the end-of-life process is not explicitly guaranteed, at least according to the Act.

The Act can be regarded as merely a tip of the iceberg, in which a fundamental structure of society, an entrenched belief system, has surfaced. A particular stance toward an individual's right to determination at the end-of-life is expressed through the Act and government policies. It is also reflected in the word choices of family members when discussing the treatment of terminal patients. This study examines the two important constituents of this belief system: government paternalism and the "dori" of individuals. These two factors become barriers to terminal patients' informed refusal.

While this paper aims to elucidate the reality of South Korea, one of the East Asian counties, it is based on the premise that there are universal values such as human dignity, human rights, and fundamental freedoms(9). As patients' informed refusal is an effective way of realizing these universal values, medical community and the society as a whole have a responsibility to guarantee it. Only with a clear understanding on status quo can this responsibility be fulfilled.

\section{Government Paternalism}

Through legislation and jurisdiction, Korea's government seeks to ensure that its citizens' lives are preserved and that their end-of-life is not expedited, displaying a sense of paternalism. Aiding and abetting suicide is criminalized in Korea(10). The judiciary has made clear through previous ruling that withdrawal of the treatment directly related to preserving a patient's life should be decided extremely restrictively and cautiously, since human life is precious and the right to life precedes all other fundamental rights under the Constitution(11). The Act stipulates the patient's right to forgo only certain types of treatments, leaving others unmentioned. As a result, for the treatments unmentioned in the Act, it is tacitly understood and assumed that they should be provided continuously.

According to the Korea's Criminal Act(10), a person guilty of aiding or abetting suicide is punishable by imprisonment for not less than one year nor more than ten years. However, regarding a patient's refusal of treatment resulting in his or her death, it remains unclear whether the doctor who followed the request of the patient is guilty of the 
crime of aiding or abetting suicide. No court ruling has declared that a death from withdrawal of treatment is categorically different from a suicide. Rather, in a court case in relation to such circumstance, forgoing of treatment is ruled permissible as the doer in that particular case did not intend to commit suicide, and therefore regarded distinct from the act of suicide(12). Therefore, the rulings do not explicitly state whether an act of treatment refusal followed by the withdrawal of treatment and the resulting death of the patient is intrinsically different from an act of suicide and therefore allowable. On the basis of medical contract, the court acknowledges that a patient has a right to self-determination with regard to medical treatment. Nonetheless, the court takes a conservative view on a patient's refusal of a treatment that could result in the subsequent withdrawal and their death: "Yet at the same time, human life is invaluable, and is essentially the most fundamental right among fundamental rights, serving as a premise for all other fundamental rights provided for in the Constitution. A doctor should practice medicine with a sense of mission to contribute to public health and owes a duty to provide patients with the best medical service available. Thus, even when a patient so requests, a doctor must be exceedingly strict and circumspect in determining whether to halt a medical treatment with a direct implication on the patient's life or to exclude specific means of treatment necessary to sustain the patient's life(11)." Likewise, in a case involving blood transfusion refusal by Jehovah's Witnesses, the ruling was that a medical treatment with a direct implication on the patient's life cannot be refused in principle: "Our Constitution upholds and respects human life as the highest value. When combined with the attitude of our Criminal Act punishing the crime of aiding and abetting suicide, and the purpose of the Emergency Medical Service Act to preserve life and eliminate any grave physical and mental harm, it ought to be deemed unacceptable, in principle, to evade a means of treatment directly implicating life in a medical emergency situation notwithstanding its high likelihood of recovery if performed(12)". The ruling lays out special circumstances in which patient's intention to refuse a treatment such as blood transfusion, which could result in shortening the patient's life, should be respected. One of which is when suicide is not the purpose of refusing a certain means of treatment. It does not clarify that a refusal of a treatment directly implicating life is distinct from a suicide in principle. Rather, it holds the view that among cases of patient's treatment refusal that have direct implications on the patient's life, some cases can be regarded as exceptions and be allowed because the purpose of refusal is not suicide. According to the ruling, people in Korea do not have the right to self-determination for every type of treatment, but for only some types of treatment. In these circumstances, the doctors cannot help but be concerned whether they would be subjected to criminal punishment for aiding or abetting suicide, when withdrawing of a treatment at a patient's request results in the patient's death.

The Act was legislated to guarantee a patient's right to self-determination and, at least partially, to clear away such anxiety of the doctors. However, the Act covers only some types of treatments. As defined by the Act, life-sustaining treatment refers to treatments provided at one's end-of-life process that merely extend the duration of the end-of-life process without curative effect; the definition does not include treatments provided before one's endof-life process. Therefore, according to the Act, patients' right to treatment refusal is not explicitly guaranteed for those who are not at one's end-oflife process. To fully understand the implications of the Act, we must focus on the distinction between the end-of-life process and terminal stage, both of which are defined by the Act. The Act defines the end-of-life process as "a state of imminent death, in which there is no possibility of revitalization or recovery despite treatment, and symptoms worsen rapidly." On the other hand, a terminal patient is defined as "a patient who has been diagnosed as expected to die within a few months from the doctor in charge and one medical specialist in the relevant field in accordance with the procedures and guidelines prescribed by Ordinance of the Ministry of Health and Welfare, because there is no possibility of a fundamental recovery, and the symptoms gradually worsen despite proactive treatment." According to the definition provided by the Act, the end-of-life process begins when a patient is much closer to death compared to the terminal stage. This can also mean that the end- 
of-life process according to the Act is a much shorter period time than the end-of-life in medical literature in general. For example, according to the guidelines provided by the Korean Academy of Medical Science to help apply the Act in actual clinical situations, signs of imminent death are given as the examples of determining whether the patient has entered the end-of-life process or not(13). The end-of-life process, according to the Act, is too limited in time for meaningful treatment refusal. Many of patients would begin suffering symptoms of imminent death during this time period.

The absence of reference to competency or mental capacity of patients in the Act is another example that demonstrates the limited scope of informed refusal permitted in Korea’s legal system. The Act provides Advance Statement on Life-Sustaining Treatment and Life-Sustaining Treatment Plan as legal documents, which correspond to advance directives and Physician Orders for Life-Sustaining Treatment (POLST) respectively, to ensure that the patient's right to refuse treatment is respected through these legal documents. Nevertheless, the Act does not confirm that these legal documents are based on the concept of a competent individual's right to choose or refuse the treatment they receive, regardless of its types. This is because an informed refusal of a patient that the legal system would like to allow falls strictly into two categories: 1) when the refusal of a treatment does not result in the patient's death, and 2) when the refusal of a treatment takes place during one's end-of-life when death is already imminent, therefore not forming any causal relationship with the patient's death. The first category is not covered in the Act and is accepted as common sense. It is only the second category that is heavily covered in the Act. When the refusal of a treatment could lead to the death of a patient, the second category is the only possible scenario in which the Act allows a patient to refuse treatment. It is reasonable to assume that a majority of the patients who fall under the second category would have already become incompetent, as they would have entered their end-of-life process. Therefore, the Act does not have to follow the logic of first referring to a competent patient's right to refuse any kinds of treatment, and then allowing patients to express their intention in advance in case they become incompetent in the future. The result of this is that the Act remains silent, perhaps intentionally, about the case of competent patients who may wish to refuse their treatments to accelerate death, a third category. The silence carries a powerful meaning on its own. As the scenario remains uncovered in the Act, competent patients will face obstacles when they wish to refuse such treatment. Unlike the second category, a refusal of a treatment during end-of-life, if a competent patient wishes to withdraw their treatment to accelerate death, there are no legal documents to help them achieve such purpose. When a document that can guarantee the legitimacy of one's action is absent, it may send a message that such an act is illegal or at least vulnerable to attack when involved in a lawsuit. Doctors are those who can practically help these patients achieve their purpose but are likely to turn down the requests of such patients for fear of criminal punishment or a possible lawsuit. Patients themselves can also feel as if their deeds do not measure up to the standard of "good acts" imposed by the nation. Ultimately, the government precisely lays out the line before which one must not give up on one's life, and effectively keeps in control one's intention to overstep that line.

\section{Individual's Dori}

In the Bioethics literature that has been formulated mainly in Western society, moral duty surrounding medical decision-making is based upon respect for the patient's right to self-determination. On the contrary, in everyday conversation in South Korea, "dori" is a word that stands out when it comes to caring for one's sick parents $(14,15,16,17)$. Dori means the right path that people should follow, bearing a close resemblance to moral duty. This word often refers to an obligation that derives from a certain role. In particular, when discussing the dori of the son or daughter of a patient, filial piety is crucial, making it their duty to take care of the parent faithfully. As a result, the following situation still occurs when a family intervenes in end-of-life treatment. A patient's family asks a doctor not to inform the patient that he or she is diagnosed with a terminal illness. At the same time, they say they seek to "fulfill one's every dori as a grown-up child" or "do one's best." they put 
the patient on every aggressive treatment that the patient may have refused and willingly pay the consequent bills. While receiving one treatment after another, the patient vaguely senses that his or her condition is not recoverable, but open discussion based on accurate information does not take place. As the disease progresses and the patient becomes incapable of making one's own decision, the family makes a decision on whether to stop the life-sustaining treatment. However, again, the patient's intention is not taken into consideration, and the treatment decision is made based upon how one's adult children want their parent to be treated. In this stage as well, their concern is about how they can fulfill their filial duty, or dori. While such expressions such as "dori" and "do my best (to fulfill that dori)" appear highly frequently in conversations, they have been rarely dealt with in the Bioethics literature. The meaning of dori, the expression commonly used in daily lives but remains elusive, should be explored in order to understand what impedes informed refusal.

Dori by its nature clashes with pluralism and individual autonomy. It is founded on the premise that there is a single form of good or rightness. Patient's autonomy emphasized in modern Bioethics is premised on autonomous agent's individuality(2:99-154). This can be best summarized in a sentence "The only freedom which deserves the name is that of pursuing our own good in our own way, so long as we do not attempt to deprive others of theirs, or impede their efforts to obtain it(18)." Based on this premise, a patient, as long as they do not harm others, can make decisions on whether to receive treatments and what kind with some degree of freedom, and should be provided with a general environment that facilitates their decision-making. The patient's decision, as long as it does not harm others, is morally neutral either way.

However, this is not the case with dori. Dori defines virtue or rightness in a positive manner and is a moral duty already inherent in a certain role. It can be explained by "jung myung" which can be translated as rectification of names, of the Analects of Confucius $(19: 46,49)$. This concept obligates the ruler to act like a ruler, the servant like a servant, the father like a father, and the son like a son. This concept is applied into daily lives. It is premi- sed on the optimism that if each family member fulfills their moral duty intrinsic to their role, a family will reach a harmonious state. Individuals are not viewed as prone to clashes with their own distinct interests and values. Therefore, it does not pay attention to what kind of unique characteristics the father has and what kind of conviction on life is driving the son's progress in life. The role of a father and that of a son are a source for moral duties. Here, the role-related duty as a son is to internalize filial piety and serve the parents well. What is problematic is, however, such duty makes it difficult to consider letting parents die as practicing filial piety. Moreover, less attention is given to the personal views of an individual who is playing the role, since the role-related duties, which are good and right acts inherent in a role, exist a priori. Eventually, a patient's family come to believe that they are not morally required to follow what a patient thinks or thought, but to act according to what their position demands. It results in less motivation to explore a patient's values and thoughts.

Discussing death is difficult in every culture. Therefore, it is hardly surprising that doctors, family, or patients themselves tend to avoid this conversation whenever possible. Role-related duty further reduces motivation to have such conversation. Because there is less moral demand for family members to understand the patient's values or thoughts regarding his or her end-of-life in advance and follow them, they become inclined to postpone the difficult conversation and even end up skipping it. After all, in their view, what is morally required for them to do as a son or daughter is to devote themselves to taking care of their parent. In this case, the patient is deprived of an opportunity to make an informed refusal based on accurate information and understanding. In the end, the patient does not get to contemplate, make decision, and make their intention clear to their family on whether to withdraw the treatment.

When a patient becomes incapable of making their own decision before providing an informed refusal or gets excluded from the decision-making process, the family who acts as a proxy for the patient tends to make a safe decision, that is, one that is tilted toward preservation of life. There is another reason beside role-related duty why decisions made by adult children for the patient tend 
to prioritize saving the patient's life. The outcome of death, which should obviously be perceived as harm generally, may be accepted depending on the particular individual's values and judgment on their own particular condition. However, adult children of the patient are not the ones who can ascribe that particular perspective to death. An outcome of a certain act, ventilator withdrawal, for instance, is a combination of many harms and benefits. Death, separation, end of pain, and no more cost would be the components and many others can also be included. A particular agent of experience is required in order to determine what these experiences mean as a whole by actually experiencing those or by predicting what these experiences would be like. Whether a certain incident is perceived as a harm or not depends on one's worldview to some extent. This is why the agent of experience is the only one who can determine if ending the pain and avoiding a life devoid of unique individual characteristics is worth submitting to death and separation. In other words, there is no one but the patient, the very agent of experience, who can actually embrace ventilator withdrawal as something else other than a harm. Therefore, when adult children act as a proxy for the patient, unless they can figure out what the patient thought, they are bound to make a decision that avoids death which is commonly perceived as a harm. While not knowing the patient's unique value system that may have defined this death as a more benefit than harm, a patient's family tend to make a safe decision to avoid death.

\section{Conclusion}

It is not possible to propose a quick fix to the aforementioned problem nor is it the paper's aim. What this paper aims to clarify are the root causes of phenomenon of lack of freedom to refuse treatment when withdrawal of a treatment could lead to the death of a patient. It is necessary to first understand the cultural and societal context if one seeks to ethically implement the Act, or even, to amend the Act in the future. I would like to emphasize the difference between the accurate description of the status quo and assertion to remain in the status quo. The analysis of this paper is aiming the former. It seeks to pave the way for future improvements in clinical decision-making, including potential amendment of the Act. It is indisputable that patients need more substantial freedom of informed refusal in the current system of end-of-life care and death. Accurate reflection on the current situation of terminal care is the first step for future change.

The current legal and cultural environment in South Korea impedes terminally ill patients from making an informed refusal to a treatment the discontinuation of which can cause death. As for a patient who has not yet reached the end-of-life process prescribed in the Act, it is unclear whether the patient is fully guaranteed the right to refuse a treatment of which withdrawal can lead to death. This is also the case even when the patient is competent and can express their decision of treatment refusal very clearly. It is the only law that grants explicit recognition of refusal to a treatment of which removal can result in death. Therefore, when doctors, patients, and families face a situation where the Act stays silent, they are left less confident about their decision. This legal vagueness is made worse by the cultural environment, making some patients, regardless of their intention, cling to life as a result. The concept of "dori," that the family of a terminal patient hold, makes them focus on practicing what is considered their duty as a son or a daughter without asking the patient's intention. Because dori reduces motivation for them to have a difficult talk about death and end-of-life, the result is that the family ends up excluding the patient, either incompetent or competent, from the decision-making process and makes a decision by themselves instead. Since there is no judgment made by the patient over the outcome as a sum of harms and benefits interpreted from his or her own worldview, the family is highly likely to make a safe decision that puts physical survival first. In this regard, the culture and the culturally influenced law are making it practically impossible for patients to make an informed refusal.

\section{Funding}

This work was supported by the Dong-A University research fund.

\section{Conflict of Interest}

The author declares no conflict of interest. 


\section{Reference}

1. Erwin C. Constitutional Law: Principles and Policies. New York, NY: Wolters Kluwer; 2015: 1235-1238.

2. Beauchamp TL, Childress JF. Principles of Biomedical Ethics. $8^{\text {th }}$ ed. New York, NY: Oxford University Press; 2019: 118-124.

3. Van Bogaert LJ. Rights of and duties to non-consenting patients-informed refusal in the developing world. Dev World Bioeth 2006; 6(1): 13-22.

4. Jacobson v. Massachusetts, 197 U.S. 11 (1905).

5. Sigman GS, O'Connor C. Exploration for physicians of the mature minor doctrine. Journal Pediatr 1991; 119(4): 520-525.

6. Faden R, Faden A. False belief and the refusal of medical treatment. J Med Ethics 1977; 3(3): 133-136.

7. National Health System (NHS). Common health questions. Available from: URL: https://www.nhs.uk/common-healthquestions/nhs-services-and-treatments/do-i-have-the-right-to-refuse-treatment/ [cited 2021 June 22].

8. The Act on Decisions on Life-Sustaining Treatment for Patients in Hospice and Palliative Care or at the End of Life. (Act No. 14013). Available from: URL: https://www.law.go.kr/engLsSc.do? menuId=1\&subMenuId=21\&tabMenuId=117\&que ry $=\% \mathrm{EC} \% 97 \% \mathrm{~B} 0 \% \mathrm{~EB} \% \mathrm{AA} \% 85 \% \mathrm{EC} \% 9 \mathrm{D} \% 98 \% \mathrm{~EB} \% \mathrm{~A} 3 \% 8 \mathrm{C} \#$ [cited 2021 May 14].

9. United Nations Educational, Scientific and Cultural Organization (UNESCO). Universal Declaration on Bioethics and Human Rights. Paris, France: UNESCO; 2005. Available from: URL: http://portal.unesco.org/en/ev.php-URL_ ID=31058\&URL_DO=DO_TOPIC\&URL_SECTION=201.html [cited 2021 June 22].

10. Criminal Act. (Act. No 14415). Available from: URL: https://www.law.go.kr/engLsSc.do? menuId=1\&subMenuId=21 \&tabMenuId=117\&query=\%ED\%98\%95\%EB\%B2\%95\# [cited 2021 May 14].

11. Supreme Court in banc Decision 2009 Da17417 Decided May 21, 2009. Available from: URL: https://library.scourt. go.kr/kor/judgment/eng_judg_view.jsp [cited 2021 May 14].

12. Supreme Court Decision 2009 Do14407 Decided June 26, 2014. Available from: URL: https://library.scourt.go.kr/kor/ judgment/eng_judg_view.jsp [cited 2021 May 14].

13. Korean Academy of Medical Science. Guideline for medical definition and judgement on terminal state and end-of-life process. Seoul: Korean Academy of Medical Science; 2016.

14. Cho MA, Kim JH. Single sons' experience and perception of caregiving for the elderly parents. Fam Cult 2021; 33(1): $1-36$.

15. Kang TW, Yeun EJ, Jeon MS. The burden types of primary care-givers for a demented elderly using Q methodology. J Korean Soc Sci Study Subjectivity 2014; 28: 53-74.

16. Won JS. An ethnographic study of caring for dying patient with cancer [Doctorate]. [Seoul (Korea)]: Ewha Womans University; 1993.

17. Park JS. A study on experiences in cohabitation-care for elderly sick parents of unmarried middle-aged women. [Doctorate]. [Cheonan (Seoul)]: Backseok University; 2019.

18. Mill JS. On liberty and other essays. New York, NY: Oxford University Press; 1998: 17.

19. Confucius. The Analects. New York, NY: Oxford University Press; 1993: 46.

Received: June 7, 2021

Accepted: July 20, 2021 